\title{
5.
}

\section{MESTRES DE FUTUR: QUAN LA LÒGICA HA DE REEIXIR}

Els estudis de Magisteri haurien de donar als estudiants una visió educativa global $i$ integradora, les capacitats necessàries per prendre decisions innovadores, habilitats cooperatives, així com els instruments de pensament reflexiu, transformador, per a una intervenció didàctica conscient i responsable. Aquests elements de canvi s'han de situar, de manera ineludible, dins d'una relació de la pràctica i de la teoria en alternança, en diàleg continuat. És evident que la situació actual no permet aquesta perspectiva, ja que ens trobem amb una multitud d'assignatures, amb una gran fragmentació acadèmica del coneixement, irracional - fruit de la nostra pròpia història-, i amb un pràcticum del tot insuficient.

El passat mes de febrer es va celebrar a Girona el Simposi sobre la formació inicial dels professionals de l'educació. En aquest simposi es va reflexionar en profunditat sobre els eixos fonamentals de la formació "què hauria de ser...", i què no és. Es va debatre sobre la formació psicològica, sociològica i pedagògica, sobre la formació científica, humanística i tecnològica del professorat, i sobre la seva formació didàctica. És a dir, es va reformular — dins les fronteres d'allò que és possiblela formació inicial, en les seves quatre grans vessants: anàlisi social, context escolar, comportament humà, $i$ presa de decisions sobre els coneixements a ensenyar.

Les característiques de la societat actual fa que sigui urgent pensar canvis dins la formació inicial. En primer lloc, cal donar als estudis de Magisteri la categoria de Llicenciatura. És una gran contradicció que des del món cultural, polític, dels mitjans de comunicació, etc., es valori com essencial una educació de qualitat i que, per contra, als professionals que han de tenir cura que en últim terme mantenen sobre les seves esquenes el procés d'ensenyament i aprenentatge- no se'Is doni una formació del màxim rang. Potser algú té por de donar als mestres la categoria d'intel-lectuals de debò? És curiós, fins i tot, observar el conservadorisme en alguns sectors que citen autors radicals o que s'anomenen a si mateixos progressistes.

En segon lloc, augmentar el temps de formació no vol dir, com pensen alguns, eixamplar el temps que les diverses àrees dediquen als estudis de Magisteri, sinó que significa anar a escola, agafar la llibreta dels apunts i anar a parlar amb els mestres d'educació infantil, primària i secundària, demanar-los que diguin quins són els problemes que tenen, quines dificultats troben per prendre decisions sobre el que han d'ensenyar, per renovar-se, per teoritzar la seva pràctica, per debatre i fer públiques les seves recerques quotidianes. És a dir, les ciències educatives s'han de dedicar a solucionar els problemes que els pertoquen i que corresponen, abans que res, a la pràctica diària de les escoles. Si la Universitat vol reinventar la seva mediocritat haurà de deixar de banda una part de la seva parafernàlia $i$ algunes "teories" buides de realitat, i trepitjar amb fermesa el món real.

La nostra societat té pendent un deute amb el món de l'ensenyament, però recela, al mateix temps, de donar més crèdit al professorat de totes les edats $i$, de retruc, al professorat universitari que ha de formar els futurs mestres. Però, el camí que s'entreveu no deixa lloc a incerteses $\mathrm{i}$, sens dubte, ensenyar serà cada vegada més important i més complex. Cada vegada es necessitaran persones millor preparades, més disposades a adaptar-se als canvis, més crítiques i més creatives. Estarem preparats per assumir totes les incerteses, totes les inquietuds, algunes inherents a l'educació, però voldríem tenir la confiança d'aquells que ens han donat la responsabilitat. Hi ha utopies que són evidències, perquè al final la lògica ha de reeixir. 